\title{
ANALYSIS OF LEARNING PROCESS ON HEREDITARY TOPICS IN BIOLOGY SUBJECT AT SMP NEGERI 2 LENGAYANG KABUPATEN PESISIR SELATAN
}

\author{
Destaria Sudirman \\ Program Studi Pendidikan Biologi FKIP Universitas Riau Kepulauan \\ Koreponeden : destaria_sudirman@gmail.com
}

\begin{abstract}
ABSTACT
The learning process can influence the student's learning achievement that is the lower of students' understanding of a subject. The lower of students' understanding of a subject is a problem that can disturb student' learning achievement. The lower of students' understanding can happen in the learning process of the heredity. This research was aimed to analyze the learning process in Biology on Heredity topics at SMP Negeri 2 Lengayang Kabupaten Pesisir Selatan which involved planning, conducting, and evaluating the learning process.

The research which was conducted at SMP Negeri 2 Lengayang Kabupaten Pesisir Selatan was a descriptive research which used qualitative approach. The sample of this research was class IX A (the third year students in group A) and class IX F (the third year students in group F). The data was gotten through observation, interview, and questionnaires. In collecting the data, the researcher used observation sheet which referred to the Regulation of National Education Ministry Number 41 Year 2007 about the standard process for primary and high educational level. Interview was conducted in order to get the data which could not be gotten through observation. Questionnaire was administered to the students to see their alertness and understanding in learning process, while video recording was used to describe the learning process.

Based on the result of the research, it was known that (1) lesson plan designed by the teacher had not yet referred to the Regulation of National Education Ministry Number 41 Year 2007, (2) the learning process conducted by the teacher which involved time allocation, learning method, learning model and learning steps had not yet based on the lesson plan designed by the teacher, and (3) the learning evaluation had not yet referred to the Regulation of National Education Ministry Number 41 Year 2007 since the teacher did evaluation only on cognitive aspect.
\end{abstract}

Keywords: Analysis, Learning, Process Hereditary

\section{PENDAHULUAN}

Proses pendidikan di sekolah merupakan proses pembelajaran yang melibatkan berbagai komponen pembelajaran diantaranya tujuan pembelajaran, siswa, guru, bahan pembelajaran, metode, media, dan situasi lingkungan belajar. Agar kegiatan pembelajaran berjalan dengan lancar semua komponen harus berfungsi. Guru sebagai tenaga pendidik merupakan komponen penentu langkah kegiatan proses pembelajaran, yaitu dalam menentukan strategi yang akan dipilih dalam proses pembelajaran. Keberhasilan penerapan strategi pembelajaran tergantung pada keterampilan yang dimiliki guru dalam menggunakan metode, media, dan model pembelajaran. Dalam proses pembelajaran guru tidak hanya sebagai pengajar tetapi juga sebagai pengelola pembelajaran. 
Guru dalam menyajikan suatu materi pelajaran kepada siswa harus memiliki perencanaan yang matang agar dalam pelaksanaan pembelajaran siswa dapat menyerap apa yang disampaikan oleh guru dan tujuan yang diinginkan guru dapat tercapai. Dalam proses pembelajaran guru juga harus memahami materi pelajaran yang diajarkannya sebagai suatu pelajaran yang dapat mengembangkan kemampuan berpikir siswa dan dapat merangsang kemampuan siswa untuk belajar, karena salah satu faktor yang menentukan berhasil atau tidaknya siswa dalam pembelajaran sangat ditentukan oleh kemampuan yang dimiliki guru dalam mengajar. Menurut Ratna (1989: 78), hasil utama yang harus dicapai peserta didik dalam pembelajaran adalah penguasaan terhadap konsep secara baik dan benar.

Hasil belajar yang tinggi adalah sesuatu hal yang diharapkan dalam proses pembelajaran karena hasil belajar yang tinggi merupakan indikasi dari keberhasilan proses pembelajaran. Hasil pembelajaran yang rendah merupakan salah satu indikasi kegagalan dalam proses pembelajaran. Tinggi rendahnya hasil pembelajaran di sekolah ditentukan oleh siswa, guru, kondisi sekolah dan sarana prasarana yang terdapat disekolah itu sendiri. Selain itu hasil pembelajaran juga ditentukan oleh kesiapan guru dalam mengajar serta media pembelajaran (perencanaan), metode dan media pembelajaran yang diberikan guru dalam proses pembelajaran (pelaksanaan) serta evaluasi yang diberikan oleh guru setelah proses pembelajaran.

Untuk mengoptimalkan proses pembelajaran seperti yang diharapkan, maka Pemerintah telah mengamanatkan standar proses yang tertera dalam Permendiknas No 41 tahun 2007. Standar proses adalah standar nasional pendidikan yang berkaitan dengan pelaksanaan pembelajaran pada satuan pendidikan untuk mencapai kompetensi lulusan yang meliputi perencanaan pembelajaran, pelaksanaan pembelajaran, evaluasi pembelajaran, dan pengawasan. Untuk melihat penyebab rendahnya pemahaman siswa dalam proses pembelajaran maka harus ditinjau dari proses pembelajaran yang dilaksanakan guru kemudian dibandingkan dengan Permendiknas No 41 tahun 2007 tentang standar proses untuk satuan pendidikan dasar dan menengah. Penelitian ini bertujuan untuk menyelidiki proses pembelajaran Biologi pada materi Pewarisan Sifat Kelas IX di SMP Negeri 2 Lengayang kabupaten Pesisir selatan meliputi: perencanaan pembelajaran, pelaksanaan pembelajaran, dan evaluasi pembelajaran.

Menurut PP No 19 Tahun 2005 Standar Nasional Pendidikan merupakan suatu acuan yang memuat kriteria minimal tentang komponen pendidikan yang memungkinkan 
setiap jenjang dan jalur pendidikan untuk mengembangkan pendidikan secara optimal sesuai dengan karakteristik dan kekhasan programnya. Standar Nasional Pendidikan berfungsi sebagai dasar dalam perencanaan, pelaksanaan dan pengawasan pendidikan dalam rangka mewujudkan pendidikan nasional yang bermutu. Standar isi dan standar proses merupakan bagian dari Standar Nasional Pendidikan.

Standar proses adalah standar nasional pendidikan yang berkaitan dengan pelaksanaan pembelajaran pada satu satuan pendidikan untuk mencapai standar kompetensi lulusan (Mulyasa, 2006: 28). Standar proses yang dimaksud telah dituangkan dalam bentuk Peraturan Menteri Pendidikan Nasional (Permendiknas) Nomor 41 Tahun 2007 tentang standar Proses untuk Satuan Pendidikan Dasar dan Menengah mencakup : (1) Perencanaan pembelajaran, (2) pelaksanaan pembelajaran, (3) penilaian hasil belajar, dan (4) tindak lanjut hasil pembelajaran. Keempat standar proses tersebut dimaksudkan untuk terlaksananya proses pembelajaran yang efektif dan efisien.

Pada Peraturan Menteri Pendidikan Nasional (Permendiknas) Nomor 20 Tahun 2007 pasal I tentang standar penilaian dinyatakan bahwa penilaian hasil belajar peserta didik pada jenjang pendidikan dasar dan menengah dilaksanakan berdasarkan standar penilaian pendidikan yang berlaku secara nasional. pada Permendiknas Nomor 41 Tahun 2007 ditegaskan bahwa penilaian dilakukan oleh guru terhadap hasil pembelajaran untuk mengukur tingkat pencapaian kompetensi peserta didik, serta digunakan sebagai bahan penyususn laporan kemajuan hasil belajar, dan memperbaiki proses pembelajaran.

Menurut Knirk dan Gustafson dalam Sagala (2003: 64) dalam proses pembelajaran terlibat tiga komponen utama yaitu guru (pendidik), siswa (peserta didik), dan kurikulum (materi pelajaran). Dalam setiap proses pembelajaran setiap metode yang dirancang oleh guru dapat membantu siswa dalam mengembangkan potensi yang dimilikinya (kognitif, afektif, dan psikomotor) secara optimal. Sehingga siswa dapat memperoleh pengalaman belajar, dan pembelajaran menjadi lebih terkesan. Dalam proses pembelajaan terdiri atas tiga tahap yaitu perencanaan, pelaksanaan, evaluasi.

Pembelajaran merupakan proses komunikasi dua arah, mengajar dilakukan oleh guru sebagai pendidik, sedangkan belajar dilakukan oleh peserta didik atau murid. Proses pembelajaran awalnya meminta guru untuk mengetahui kemampuan dasar yang dimiliki siswa meliputi kemampuan dasarnya, motivasinya, latar belakang akademisnya, latar belakang sosial dan ekonominya. Kesiapan guru untuk mengenal karakteristik siswa dalam 
pembelajaran merupakan modal utama penyampaian bahan belajar dan menjadi indikator suksesnya pelaksanaan pembelajaran (Sagala, 2003: 61).

Dalam pembelajaran guru harus memahami materi pelajaran yang diajarkanya sebagai suatu pelajaran yang dapat mengembangkan kemampuan berpikir siswa dan memahami berbagai model pembelajaran yang dapat merangsang kemampuan siswa untuk belajar dengan perencanaan yang matang oleh guru. Selain menguasai materi pelajaran, guru diharuskan juga menguasai metode pengajaran sesuai kebutuhan materi ajar yang mengaju pada prinsip pedagogik, karena salah satu faktor yang menentukan berhasil atau tidaknya siswa dalam pembelajaran sangat ditentukan oleh kemampuan yang dimiliki guru dalam mengajar.

\section{METODE PENELITIAN}

Penelitian ini menggunakan metode penelitian deskriptif dengan pendekatan kualitatif . Observasi dilaksanakan untuk perangkat mengajar dan proses pembelajaran, yaitu mengetahui kesesuaian pelaksanaan proses pembelajaran guru dengan RPP, teknik mengajar guru, sumber-sumber belajar yang dipakai, dan media yang digunakan pada saat proses pembelajaran. Wawancara dilakukan kepada guru dan siswa untuk data lebih mendalam sedangkan angket diberikan kepada siswa kelas IX A dan IX F untuk data penunjang observasi dan wawancara.

\section{HASIL DAN PEMBAHASAN}

\section{Proses Pembelajaran}

\section{Perencanaan Pembelajara}

Hasil analisis terhadap RPP menunjukkan bahwa dari segi format RPP yang digunakan guru pada proses pembelajaran pada materi pewarisan sifat belum mengacu pada Permendiknas Nomor 41 Tahun 2007. RPP tersebut terdiri dari 10 komponen dimana seharusnya RPP terdiri dari 11 komponen. Hasil analisis isi RPP menunjukkan bahwa beberapa komponen RPP tersebut belum sesuai dengan Permendiknas nomor 41 Tahun 2007. 


\section{RENCANA PELAKSANAAN PEMBELAJARAN (RPP)}

Jenjang Sekolah

Mata Pelajaran

Kelas / Semester

Alokasi Waktu

\author{
SMP N 2 Lengayang \\ IPA Terpadu \\ IX $/ 1$ \\ $4 \times 40$ menit ( $2 \times$ Pertemuan )
}

Gambar 1. Salinan identitas mata pelajaran dari RPP guru

Dalam RPP, guru telah mencantumkan SK dan KD. Namun, tidak mencantumkan indikator pembelajaran dengan alasan telah ada dalam silabus. Hal ini tidak sesuai dengan format Permendiknas Nomor 41 Tahun 2007. Indikator yang dicantumkan guru dalam silabus belum sesuai dengan KD. Tujuan pembelajaran yang dibuat guru juga belum mengacu pada KD untuk materi ini dan belum sepenuhnya memuat $\mathrm{ABCD}$ (audience, behavior, condition, dan degree). Guru menulis 3 tujuan pembelajaran seharusnya tujuan pembelajaran yang seharusnya dibuat guru adalah sebagai berikut.

1. Setelah mempelajari materi ini siswa mampu menjelaskan materi genetik yang bertanggung jawab dalam pewarisan sifat.

2. Setelah mempelajari materi ini siswa mampu menjelaskan istilah-istilah dalam pewarisan sifat.

3. Setelah mempelajari materi ini siswa mampu menjelaskan definisi persilangan antara dua individu dengan satu sifat beda atau lebih.

4. Setelah mempelajari materi ini siswa mampu memberikan contoh persilangan antara dua individu dengan satu sifat beda atau lebih

5. Setelah mempelajari materi ini siswa mampu menentukan sifat dominan, resesif, dan itermediet pada kedua induk yang muncul pada keturunan pertama.

6. Setelah mempelajari materi ini siswa mampu menentukan rasio hasil persilangan monohibrid dan dihibrid.

7. Setelah mempelajari materi ini siswa mampu menjelaskan penerapan pewarisan sifat dalam kehidupan sehari-hari. 
Materi pelajaran yang dibuat guru pada RPP belum sesuai dengan format Permendiknas Nomor 41 Tahun 2007. Guru hanya memuat judul dari materi pelajaran, dimana seharusnya berdasarkan Permendiknas Nomor 41 Tahun 2007 dalam materi pelajaran tersebut termuat fakta, konsep, prinsip, dan prosedur yang relevan yang ditulis dalam butir-butir sesuai dengan rumusan indikator pencapaian kompetensi.

Kegiatan pembelajaran yang ditulis tidak sesuai dengan model pembelajaran yang ada di RPP. Dalam hal ini terlihat bahwa guru belum memahami model pembelajaran yang digunakan. Sintaks dari model pembelajaran langsung adalah; (1) menyampaikan tujuan dan motivasi siswa, (2) mempresentasikan pengetahuan/mendemonstrasikan keterampilan, (3) memberi latihan terbimbing, (4) mengecek pemahaman dan memberi umpan balik, dan (5) memberi latihan lanjutan dan transfer (Nur, 2005: 14). Sedangkan sintaks dari model pembelajaran kooperatif adalah; (1) guru menyampaikan tujuan pembelajaran, (2) guru menyampaikan materi secara garis besar, (3) guru membentuk beberapa kelompok dengan 4-6 siswa yang memiliki kemampuan yang heterogen, (4) siswa secara berkelompok menuntaskan materi pembelajaran hari itu yang dibantu dengan LKS yang sudah dirancang guru, (5) perwakilan kelompok mempresentasikan hasil diskusi, (6) guru memberi penghargaan pada kelompok, dan (7) guru dan siswa bersama-sama menyimpulkan pelajaran hari itu (Muslimin, 2005: 21).

Penilaian yang dibuat guru pada RPP hanya terdiri dari penilaian kognitif saja sedangkan penilaian afektif dan penilaian psikomotor tidak dibuat oleh guru. Pada RPP guru juga tidak ada mencantumkan KKO ranah kognitif dan kisi-kisi soal ulangan harian. Jadi rencana penilaian yang dilaksanakan guru belum sesuai dengan Permendiknas Nomor 20 Tahun 2007.

\section{Pelaksanaan Pembelajaran}

Proses pembelajaran yang dilaksanakan guru tidak sesuai dengan RPP yaitu 4 x 40 menit. Proses pembelajaran dilaksanakan hanya selama 70 menit pada kelas IX A dan IX F. Hal ini disebabkan karena keterlambatan siswa karena jam masuk pembelajaran di awal pelajaran dan setalah jam istirahat. Selain itu, pada pertemuan kedua siswa belajar di laboratorium untuk melakukan praktikum. Keterlambatan siswa masuk kedalam kelas ini juga sangat mempengaruhi kelancaran proses pembelajaran. 
Proses pembelajaran terdiri dari kegiatan pendahuluan, kegiatan inti, dan kegiatan penutup. Namun, kegiatan pembelajaran yang dilaksanakan guru tidak sesuai dengan metode dan model pembelajaran yang ditulis di RPP. Contohnya, dalam pelaksanaan proses pembelajaran pada kegiatan awal guru mengecek kehadiran siswa dan mereview kembali materi yang telah dipelajari sebelumnya, tetapi hal ini tidak tercantum dalam RPP yang dibuat guru.

Pada saat proses pembelajaran, guru menjelaskan materi pembelajaran dengan menggunakan metode ceramah dan tanya jawab, sehingga siswa hanya fokus terhadap penjelasan guru. Berdasarkan wawancara, guru menggunakan metode ceramah dan tanya jawab sesuai dengan karakteristik siswa yang sebagian besar tidak memiliki buku pembelajaran. Guru seharusnya melaksanakan pembelajaran sesuai dengan metode pembelajaran yang tertera pada RPP yaitu metode diskusi informasi, sehingga siswa aktif dan tidak hanya menerima apa yang diberikan oleh guru, tetapi pembelajaran dapat berpusat kepada siswa dan guru hanya sebagai fasilitator pembelajaran. Hal ini sesuai dengan yang diungkapkan Lufri (2007: 34) bahwa kelebihan metode diskusi adalah:

1) dapat melibatkan anak didik secara langsung dalam pembelajaran,

2) pemecahan masalah secara bersama lebih baik daripada sendirian atau individu,

3) dapat mengembangkan kemampuan berpikir kreatif, kritis, dan berpikir tingkat tinggi anak didik,

4) dapat mengembangkan kompetensi sosial dan sikap demokrasi,

5) dapat menyadarkan anak didik bahwa masalah dapat dipecahkan dengan berbagai jalan dan bukan satu jalan,

6) dapat menyadarkan anak didik bahwa dengan berdiskusi mereka saling mengemungkakan pendapat secara konstruktif sehingga dapat diperoleh keputusan yang lebih baik,

7) dapat membiasakan anak didik untuk mendengarkan pendapat orang lain sekalipun berbeda dengan pendapatnya sendiri dan membiasakan bersifat toleran.

Hal ini berdampak pada rendahnya aktivitas dan hasil belajar siswa. Aktivitas siswa terbatas yaitu hanya menjawab pertanyaan yang dilontarkan guru dan bertanya kepada guru. Siswa tidak dapat menggali pengetahuan sendiri hanya terpaku kepada guru. Selain itu, dalam proses pembelajaran guru juga hanya menunjuk siswa yang 
pintar saja yang berinisial A dan B dalam menjawab pertanyaan yang dilontarkan guru, sehingga siswa yang memiliki kemampuan sedang dan rendah tidak diberi kesempatan untuk berpikir dalam menjawab pertanyaan tersebut.

Pada saat proses pembelajaran guru juga terlalu banyak menghabiskan waktu menjelaskan satu topik, sehingga alokasi waktu tidak mencukupi untuk menjelaskan semua tujuan pembelajarn yang direncanakan. Contoh dari tujuan pembelajaran yang tidak tercapai yaitu tentang persilangan dihibrid, karena waktu yang terbatas.

Guru belum dapat mengelola kelas dengan baik, hal ini terlihat pada kelas IX F dimana ketika guru menerangkan ada seorang siswa yang duduk bagian depan asik membuat tugas mata pelajaran lain dan ada beberapa orang siswa yang tidak memperhatikan saat guru menerangkan pelajaran. Guru memberikan penguatan dan umpan balik terhadap respon dan keberhasilan belajar siswa, guru menghargai pendapat siswa, dan guru telah memakai pakaian yang sopan, rapi, dan bersih. Namun, guru dalam memulai dan mengakhiri pembelajaran tidak sesuai dengan waktu yang telah ditetapkan sehingga waktu yang telah direncanakan dalam RPP tidak sesuai dengan waktu yang dilaksanakan dalam pembelajaran sehingga terdapat tujuan pelajaran yang tidak terlaksana sebagaimana mestinya.

Pada kegiatan penutup guru tidak menyimpulkan materi pelajaran yang telah dipelajari, tetapi guru hanya memberikan tugas rumah kepada siswa untuk meringkas materi yang telah dipelajari. Kegiatan ini tidak sesuai dengan RPP yang telah dibuat guru.Sarana dan media pembelajaran yang tersedia di SMP Negeri 2 Lengayang Kabupaten Pesisir Selatan belum memadai. Hal ini terlihat dari kurangnya jumlah buku yang terdapat diperpustakaan sekolah sehingga tidak mencukupi jumlah siswa. Selain itu, alat-alat yang terdapat di laboratorium juga tidak lengkap. Terbukti dari tidak cukupnya kancing genetika pada saat praktikum, sehingga guru mengurangi jumlah kancing genetika dari 100 buah perkelompok menjadi 50 buah perkelompok.

\section{Evaluasi Pembelajaran}

penilaian hasil pembelajaran yang dilaksanakan guru belum sesuai dengan Permendiknas Nomor 20 Tahun 2007, karena guru hanya melaksanakan penilaian kognitif saja, tetapi penilaian afektif dan psikomotor tidak dilaksanakan. Berdasarkan wawancara dengan guru, penilaian psikomotor tidak dilakukan karena guru tidak menyiapkan rubrik 
untuk penilaian psikomotor. Selain itu, guru juga tidak membuat kata kerja operasional (KKO) untuk penilaian kognitif dan kisi-kisi soal. Seharusnya dalam membuat sebuah soal, guru harus membuat kisi-kisi soal yang mengacu pada indikator pencapaian kompetensi dan harus mengelompokkan soal tersebut berdasarkan tingkatan ranah kognitif.

Setelah peneliti melakukan analisis soal ulangan harian materi pewarisan sifat, diketahui dari 10 soal objektif dan 3 soal esay ada 2 soal yang mengacu pada tujuan pembelajaran yang tidak dipelajari pada saat proses pembelajaran, dan 4 soal yang tidak bisa dijawab karena soalnya salah. Soal yang mengaju pada tujuan pembelajaran yang tidak dipelajari pada saat proses pembelajaran yaitu soal objektif nomor 8 tentang persilangan antara tanaman bergenotip AABB dengan aabb akan menghasilkan perbandingan fenotip F2 berapa, dan pada soal esay terdapat pada soal nomor 3 yaitu tikus jantan berambut hitam disilangkan dengan tikus betina berambut putih, menghasilkan keturunan semua berwarna abu-abu, bila tikus abu-abu disilangkan sesamanya bagaimana perbandingan genotip dan fenotip pada F2-nya.

Ulangan harian yang diberikan kepada siswa berupa soal pilihan ganda terdiri dari 10 buah soal dan 3 soal dalam bentuk esay, dimana soal-soal ulangan harian yang dibuat guru tingkatan kesulitan soalnya berkisar antara C1 sampai dengan $\mathrm{C} 3$.

\section{Analisis Terhadap Siswa}

Hasil deskripsi data angket kesiapan dan pemahaman siswa dalam proses pembelajaran dapat diketahui bahwa pemahaman siswa sangat kurang dalam proses pembelajaran dan persiapan siswa dalam mengahadapi ulangan harian yang diberikan oleh guru juga sangat kurang. Selain itu, rendahnya hasil ulangan harian siswa pada materi pewarisan sifat juga disebabkan karena guru tidak melaksanakan pembelajaran student center, sehingga siswa hanya menerima informasi dari guru. Informasi yang diterima dari guru juga tidak dicatat dengan baik oleh siswa. Hal ini terbukti dari catatan siswa yang tidak lengkap, padahal guru juga telah memberi tugas untuk meringkas materi yang telah dipelajari dirumah. Selain itu yang menjadi penyebab adalah guru tidak menuntaskan materi pelajaran sesuai waktu yang disediakan, guru hanya memberi tugas individual kepada siswa untuk mempelajari materi yang tidak tersampaikan dalam pembelajaran dirumah. Hal lain yang juga menyebabkan rendahnya pemahaman siswa adalah karena 
adanya soal ulangan harian yang diberikan guru tidak sesuai dengan apa yang dipelajari pada saat pembelajaran. Contoh jawaban ulangan harian siswa sebagai berikut:
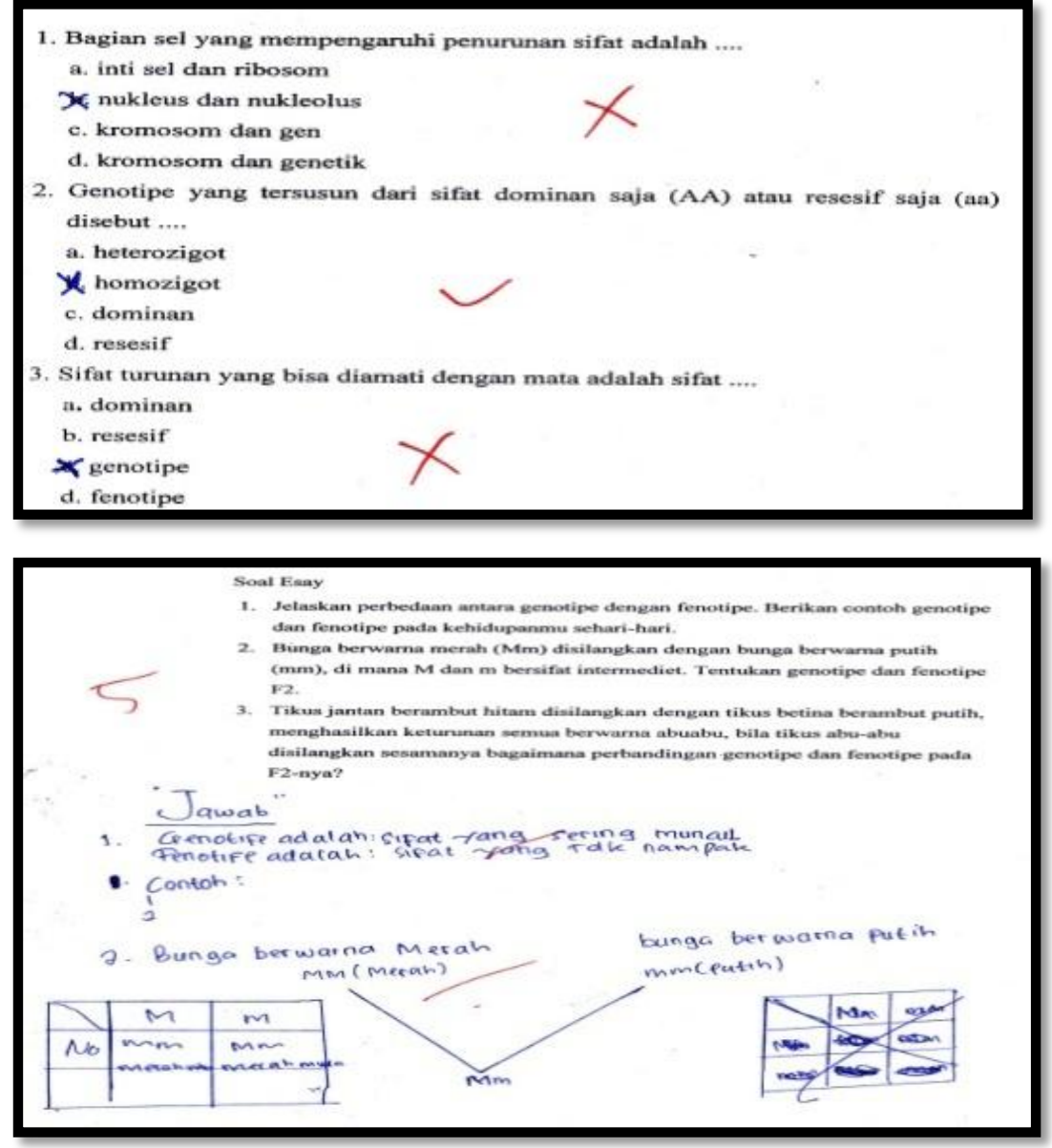

Gambar 2. Salinan Soal Ulangan Harian Pewarisan Sifat

Penyebab rendahnya hasil ulangan harian siswa terhadap materi pewarisan sifat tidak hanya disebabkan oleh guru, namun juga disebabkan oleh siswa. Dari deskripsi proses pembelajaran dapat diketahui bahwa banyak siswa yang tidak serius dalam mengikuti proses pembelajaran. Hal ini terlihat pada salah seorang siswa kelas IX F yang asik membuat tugas pelajaran lain pada saat guru menerangkan pembelajaran sehingga menyebabkan kurangnya pemahaman siswa terhadap materi pewarisan sifat. Selain itu, kebanyakan siswa hanya berpura-pura dalam memperhatikan penjelasan dari guru. Hal ini terbukti pada saat guru bertanya hanya beberapa orang siswa yang dapat menjawab pertanyaan guru dengan benar. Selain itu, siswa juga tidak mengulang materi yang telah dipelajar dirumah dan dapat dibuktikan dari angket yang telah dijalankan kepada siswa serta hasil wawancara dengan siswa, diketahui bahwa siswa pada umumnya tidak 
mengulangi materi pelajaran dirumah karena siswa tidak memiliki buku pelajaran dan catatan yang dimilikipun tidak lengkap.

Jika ditelusuri lebih lanjut dari angket yang dijalankan kepada siswa dapat diketahui penyebab rendahnya nilai siswa pada materi pewarisan sifat karena sangat kurangnya kesiapan siswa dalam proses pembelajaran dan kurangnya pemahaman siswa selama proses pembelajaran. Selain itu, siswa juga mengungkapkan mereka tidak mempunyai buku pelajaran sehingga menyebabkan siswa tidak dapat belajar terlebih dahulu di rumah.

Berdasarkan analisis tersebut dapat diketahui bahwa rendahnya nilai ulangan harian siswa pada materi pewarisan sifat tidak hanya disebabkan oleh guru, tetapi juga disebabkan oleh sangat kurangnya kesiapan siswa dalam proses pembelajaran dan kurangnya pemahaman siswa dalam proses pembelajaran. Selain itu juga disebabkan karena kurangnya buku penunjang dalam proses pembelajaran yang dimiliki siswa.

\section{KESIMPULAN}

Perencanaan proses pembelajaran yang dilaksanakan oleh guru di kelas IX A dan IX F di SMP Negeri 2 Lengayang Kabupaten Pesisir Selatan dari segi format belum mengacu pada Permendiknas Nomor 41 Tahun 2007. Dalam perencanaan tidak dicantumkan indikator pencapaian kompetensi. Hal yang sama terlihat dari segi isi, komponen yang belum sesuai yaitu:

a. pada identitas mata pelajaran, dimana jenjang sekolah seharusnya guru menuliskan satuan pendidikan dan pada alokasi waktu seharusnya guru menuliskan jumlah pertemuan

b. indikator pencapaian kompetensi yang tertera pada silabus juga tidak sesuai dengan $\mathrm{KD}$

c. tujuan pembelajaran yang dibuat guru belum mengacu pada $\mathrm{KD}$ dan belum sepenuhnya memuat $\mathrm{ABCD}$ dan,

d. materi pembelajaran yang dibuat guru belum mencakup fakta, konsep, prinsip, dan prosedur yang relevan yang ditulis dalam butir-butir indikator pencapaian kompetensi. 
Pelaksanaan pembelajaran materi pewarisan sifat yang dilaksanakan oleh guru biologi di kelas IX A dan IX F di SMP Negeri 2 Lengayang Kabupaten Pesisir Selatan belum sesuai dengan RPP yang dibuat guru seperti:

a. alokasi waktu pada pelaksanaan proses pembelajaran tidak sesuai dengan RPP yang dibuat guru

b. metode pembelajaran yang digunakan guru tidak sesuai dengan RPP guru, pada kegiatan awal guru mengecek kehadiran siswa dan mereview kembali materi yang telah dipelajari sebelumnya tetapi hal ini tidak tercantum dalam RPP yang dibuat guru

c. dalam penyampaikan materi ada beberapa konsep yang salah

d. tidak tercapainya tujuan pembelajaran yang telah direncanakan guru

e. pada kegiatan penutup guru tidak menyimpulkan pembelajaran, dan saranaprasarana yang belum memadai.

Penilaian hasil pembelajaran yang dilaksanakan guru belum sesuai dengan standar penilaian berdasarkan Permendiknas Nomor 20 Tahun 2007, karena dalam RPP guru hanya merencanakan penilaian kognitif saja, guru tidak membuat penilaian afektif dan psikomotor. Penilaian kognitif yamg dilakukan guru berupa ulangan harian dan pengisian LKS pada kegiatan pratikum.

\section{REFERENSI}

Lufri. 2007. Strategi Pembelajaran Biologi. FMIPA UNP. Padang.

Mulyasa, E. 2006. KurikulumTingkat Satuan Pendidikan. PT Remaja Rosdakarya. Bandung.

Muslimin., Ibrahim., Rachmadiarti, F., Nur, M., dan Ismono. 2005. Pembelajaran Kooperatif. UNS Pusat Sains dan Matematika Sekolah. Surabaya.

Nur, M. 2005. Guru yang Berhasil dan Model Pengajaran Langsung. Depdiknas. Jakarta.

Peraturan Pemerintah Nomor 19 Tahun 2005 Tentang Standar Nasional Pendidikan. 2005. Badan Standar Nasional Pendidikan. Jakarta.

Peraturan Menteri Pendidikan Nasional Republik Indonesia Nomor 41 Tahun 2007 Tentang Standar Proses Pendidikan Dasar dan Menengah. 2007. Badan Standar Nasional Pendidikan. Jakarta. 
Peraturan Menteri Pendidikan Nasional Republik Indonesia Nomor 20 Tahun 2007 Tentang Standar Penilaian Pendidikan. 2007. Badan Standar Nasional Pendidikan. Jakarta.

Ratna, W. D. 1989. Teori - teori Belajar. Erlangga. Jakarta.

Sagala, S. 2003. Konsep dan Makna Pembelajaran. CV Alfabeta. Bandung. 